\title{
Analisis Faktor-Faktor yang Mempengaruhi Keputusan Pembelian Produk pada McDonald's di Jatiasih Bekasi
}

\author{
Analysis of Factors Affecting Product Purchasing Decision at McDonald's in \\ Jatiasih Bekasi
}

\author{
Abdul Basith $^{1 *}$, Faris Fadhilah ${ }^{1}$ \\ 1) Departemen Manajemen, Fakultas Ekonomi dan Manajemen, IPB Kampus Dramaga Bogor 16680
}

\begin{abstract}
The development of new era leads people to be fast and practical person on all activity. Include culture of choosing food and drink consumers choose fast food. The purpose of this study was to identify the characteristics of consumers, analyze the purchasing decision making process, and analyze the factors that influence consumer decision making. The method used in this research is a descriptive analysis and factor analysis use SPSS 25 for windows. The research result consumers characteristic at McDonald's Jatiasih is female, last education senior high school, job as students and ten major factors influence consumer purchase decisions at McDonald's, the factors consist of enviroment impact, the habits of individuals, marketing mix, activity, time, product attractiveness, knowledge and physical condition. Time factor is the strongest factors impact consumers buyer decision and dayime is the priority factors.
\end{abstract}

Keywords: factor analysis, McDonald's, purchase decision

\begin{abstract}
ABSTRAK
Perkembangan jaman modern menuntun masyarakat untuk beraktifitas secara cepat dan praktis. Salah satunya budaya dalam memilih makanan atau minuman yaitu makanan cepat saji. Penelitian ini bertujuan untuk mengidentifikasi karakteristik konsumen, menganalisis proses keputusan pembelian produk oleh konsumen dan menganalisis faktor-faktor yang berkontribusi pada pengambilan keputusan pembelian produk oleh kosumen. Metode yang digunakan dalam penelitian ini adalah analisis deksriptif dan analisis faktor menggunakan program SPSS 25. Hasil penelitian menunjukkan bahwa karakteristik konsumen McDonald's Jatiasih merupakan perempuan, pendidikan terakhir SMA, usia remaja, profesi pekerjaan sebagai pelajar atau mahasiswa dan terdapat sepuluh faktor yang mempengaruhi keputusan pembelian produk oleh konsumen McDonald's, yaitu faktor pengaruh lingkungan, kebiasaan individu, bauran promosi produk, aktifitas, waktu, daya tarik produk, asumsi pribadi, keunikan produk, pengetahuan dan kondisi fisik. Faktor waktu merupakan faktor terkuat yang mempengaruhi keputusan pembelian konsumen degan variable di siang hari.
\end{abstract}

Kata kunci: analisis faktor, keputusan pembelian, McDonald's

*Corresponding author

Alamat e-mail: basith57@yahoo.com 


\section{PENDAHULUAN}

Perkembangan teknologi dan industri pangan memudahkan masuknya budaya asing ke Indonesia, salah satunya adalah budaya konsumi makanan cepat saji. Begitu pula dengan budaya konsumsi makanan masyarakat membutuhkan hal yang praktis dan cepat salah satunya yaitu makanan cepat saji. Munculnya restoran makanan cepat saji dijadikan solusi bagi beberapa kalangan masyarakat tertentu sebagai pilihan utama dalam konsumsi makanan. Menurut Zyl et al. (2010), telah terjadi peningkatan signifikan dalam pembelian produk makanan cepat saji dan mengakibatkan pertumbuhan cepat dari industri makanan cepat saji di dunia. Badan Pusat Statistik Indonesia melakukan penelitian mengenai sumber konsumsi kalori dan protein penduduk Indonesia dan Provinsi, survei yang dilakukan pada tahun 2013-2017 ditunjukkan pada Tabel 1.

Tabel 1. Rata-rata konsumsi kalori protein pedesaan dan perkotaan Indonesia per kapita sehari periode $2013-2017$.

\begin{tabular}{lcccccccc}
\hline & \multicolumn{4}{c}{ Protein (gram) } & \multicolumn{3}{c}{ Kalori (kcal) } \\
\cline { 2 - 9 } Tahun & $\begin{array}{c}\text { Padi- } \\
\text { padian }\end{array}$ & Daging & $\begin{array}{c}\text { Ikan/ } \\
\text { Udang }\end{array}$ & $\begin{array}{c}\text { Makanan } \\
\text { Minuman } \\
\text { Jadi }\end{array}$ & $\begin{array}{c}\text { Padi- } \\
\text { padian }\end{array}$ & Daging & $\begin{array}{c}\text { Ikan/ } \\
\text { Udang }\end{array}$ & $\begin{array}{c}\text { Makanan } \\
\text { Minuman } \\
\text { Jadi }\end{array}$ \\
\hline Maret 2017 & 20,02 & 4,20 & 8,23 & 14,56 & 851,44 & 67,70 & 49,17 & 498,30 \\
September 2016 & 20,29 & 5,70 & 8,18 & 12,67 & 863,83 & 83,73 & 48,72 & 443,22 \\
September 2015 & 20,5 & 3,24 & 7,47 & 10,65 & 872,17 & 53,83 & 44,45 & 379,29 \\
Maret 2014 & 20,36 & 2,68 & 7,51 & 9,34 & 867,64 & 45,30 & 43,33 & 305,75 \\
Maret 2013 & 20,57 & 2,47 & 7,34 & 8,75 & 876,58 & 39,96 & 44,09 & 291,90 \\
\hline
\end{tabular}

Sumber: Badan Pusat Statistik (2013-2017)

Tabel 1 menunjukkan urutan konsumsi sumber kalori dan protein masyarakat Indonesia yaitu urutan satu adalah padi-padian, urutan dua adalah makanan dan minuman jadi, urutan tiga adalah ikan/udang dan urutan terakhir adalah daging. Makanan dan minuman cepat saji (fastfood) merupakan faktor kedua sebagai kebutuhan masyarakat Indonesia dalam memenuhi kebutuhan kalori dan protein setiap hari. Dari tahun 2013 - 2017, tingkat konsumsi makanan dan minuman jadi masyarakat Indonesia terus meningkat yaitu dari 8,75 - 14,56 untuk protein dan 291,90 498,30 untuk kalori. Hal tersebut menunjukkan bahwa masyarakat Indonesia masih antusias terhadap makanan dan minuman cepat saji.

Outlet makanan cepat saji asal mancanegara terus membuka cabang baru di kota-kota besar maupun daerah lain di Indonesia. Hal tersebut disebabkan karena pesatnya perkembangan restoran fast food dan pasar yang menjanjikan. Kecepatan dalam pemesanan dan penyajian yang menarik membuat banyak masyarakat Indonesia mulai mencoba dan menggemari makanan fast food dari kalangan muda hingga tua. Beragam jenis restoran fast food bermunculan, hal tersebut terjadi karena adanya permintaan pasar yang menjanjikan. Persentase pertumbuhan waralaba di Jawa Barat dapat dilihat pada Gambar 1.

Jurnal Manajemen dan Organisasi (JMO),

Vol. 9 No. 3 , Desember 2018, Hal. 191-201

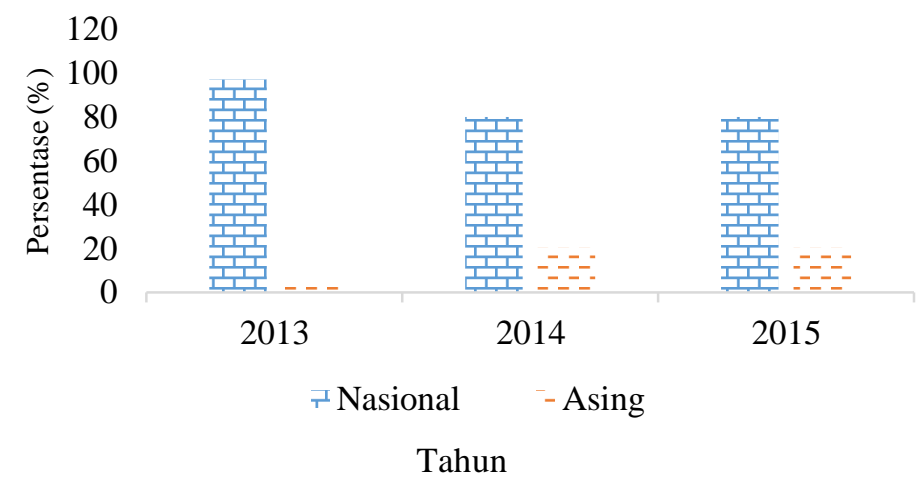

Gambar 1. Persentase jenis waralaba Indonesia Sumber: Badan Pusat Statistik (2013-2015) 
Berdasarkan Gambar 1, dapat disimpulkan bahwa persentase outlet makanan cepat saji atau restoran asing di Jawa Barat mengalami pertumbuhan yang sangat tinggi yaitu pada tahun 2013 - 2014 dengan persentase pertumbuhan 18 persen. Namun pada tahun $2014-2015$ jenis waralaba asing tidak mengalami pertumbuhan karena outlet asing lebih memilih untuk memperbanyak outlet mereka. Top Brand Award sebagai perusahaan analisis brand performance telah melakukan survey terkait Top Brand restoran di Indonesia. Banyaknya pilihan restoran cepat saji yang populer di Indonesia dapat dikategorikan berdasarkan jenis makanannya. Adapun dalam kategori restoran fast food, yang termasuk dalam Top Brand Award 2017 fase 2 disajikan pada Tabel 2.

Tabel 2. Top brand index restoran fast food

\begin{tabular}{lll}
\hline \multicolumn{1}{c}{ Merk } & TBI & TOP \\
\hline KFC & $60,4 \%$ & TOP \\
MC Donald's & $19 \%$ & TOP \\
Hoka-Hoka Bento & $3,7 \%$ & \\
A \& W & $2,9 \%$ & \\
FC & $2,7 \%$ & \\
\hline
\end{tabular}

Sumber: Top Brand Award 2017 Fase 2

Berdasarkan Tabel 2, McDonald's berada pada peringkat ke dua Top Brand restoran fast food di Indonesia, meskipun hanya menempati posisi ke dua dengan nilai 19 persen, McDonald's masih termasuk dalam kategori Top Brand di kalangan konsumen. Outlet McDonald's di Indonesia tersebar diseluruh penjuru wilayah Indonesia, terutama di kota-kota besar namun terdapat pula di berbagai daerah, yaitu beberapa di Ibu kota Jakarta dan kota lain sekitarnya seperti Bogor, Depok, Tangerang, dan Bekasi. Restoran McD di Kota Bekasi berjumlah 7 buah, yaitu restoran yang berlokasi di Cut Meutia Bekasi, Summarecon Bekasi, Jatiwarna, Pekayon, Kota Harapan Indah, Kota Bintang dan Jatiasih.

Ketatnya persaingan antara waralaba asing dan nasional mengharuskan setiap perusahaan untuk menciptakan hal-hal yang unik dan menarik agar dapat bersaing dengan para kompetitornya. Perusahaan juga harus mampu memenuhi kebutuhan dan keinginan konsumen agar produknya selalu dipilih untuk dibeli. Perilaku konsumen merupakan aktivitas dan tindakan yang dilakukan oleh individu, kelompok, atau organisasi yang berhubungan dengan keputusan untuk mendapatkan dan menggunakan produk berupa barang maupun jasa yang dapat dipengaruhi oleh lingkungan (Swastha dan Irawan 2003).

Keputusan pembelian produk yang dilakukan konsumen merupakan salah satu aspek penting dari perilaku konsumen ini. Pelaku bisnis, dalam penelitian ini adalah McDonald's, sebaiknya mengetahui proses pengambilan keputusan dan faktor-faktor yang berkontribusi terhadap keputusan konsumen dalam melakukan pembelian produk mereka agar dapat senantiasa meningkat jumlah penjualannya yang berujung pada peningkatan profit perusahaan. Berdasarkan permasalahan tersebut maka rumusan masalah dalam penelitian ini adalah: 1) Bagaimana karakteristik konsumen McDonald's Jatiasih Bekasi?; 2) Bagaimana proses pengambilan keputusan pembelian yang dilakukan konsumen McDonald's Jatiasih?; 3) Faktor-faktor apa yang berkontribusi pada pengambilan keputusan pembelian produk oleh konsumen di restoran McDonald's?.

Penelitian ini bertujuan untuk: 1) Mengidentifikasi karakteristik konsumen restoran McDonald's Jatiasih. 2) Menganalisis proses keputusan pembelian yang dilakukan konsumen McDonald's Jatiasih. 3) Menganalisis faktor-faktor yang berkontribusi pada pengambilan keputusan pembelian produk oleh konsumen di restoran McDonald's.

\section{METODE PENELITIAN}

Perkembangan zaman modern membutuhkan segala sesuatu yang cepat dan praktis tak terkecuali budaya konsumsi makanan. Outlet makanan cepat saji terus berkembang di kota-kota besar maupun daerah hal ini terjadi karena pasar yang menjanjikan. Salah satu outlet McD terdapat di daerah Jatiasih, yang menjadi obyek penelitian ini. Dalam radius 1 kilometer dari lokasi obyek penelitian, juga terdapat berbagai waralaba asing seperti, McDonald's, KFC, CFC,

Jurnal Manajemen dan Organisasi (JMO), Vol. 9 No. 3 , Desember 2018, Hal. 191-201 
Dunkin Donuts, Pizza Hut, Domino dan McD Jatiasih merupakan outlet yang paling banyak dikunjungi.

Proses penelitian ini mencakup dua tahap analisis. Analisis pertama yaitu analisis deksriptif, yang digunakan untuk mengidentifikasi karakteristik konsumen dan menganalisis proses keputusan pembelian. Analisis ke dua yaitu analisis faktor untuk mengidentifikasi faktorfaktor yang mempengaruhi keputusan pembelian produk McDonald's, setelah dilakukan analisis factor terbentuk 10 faktor baru dengan faktor terkuat, yaitu faktor waktu. Hasil dari dua analisis tersebut akan menghasilkan suatu implikasi manajerial perilaku konsumen yang dapat menjadi rekomendasi bagi pihak McDonald's Jatiasih Bekasi. Secara ringkas kerangka pemikiran dapat dilihat pada Gambar 3.

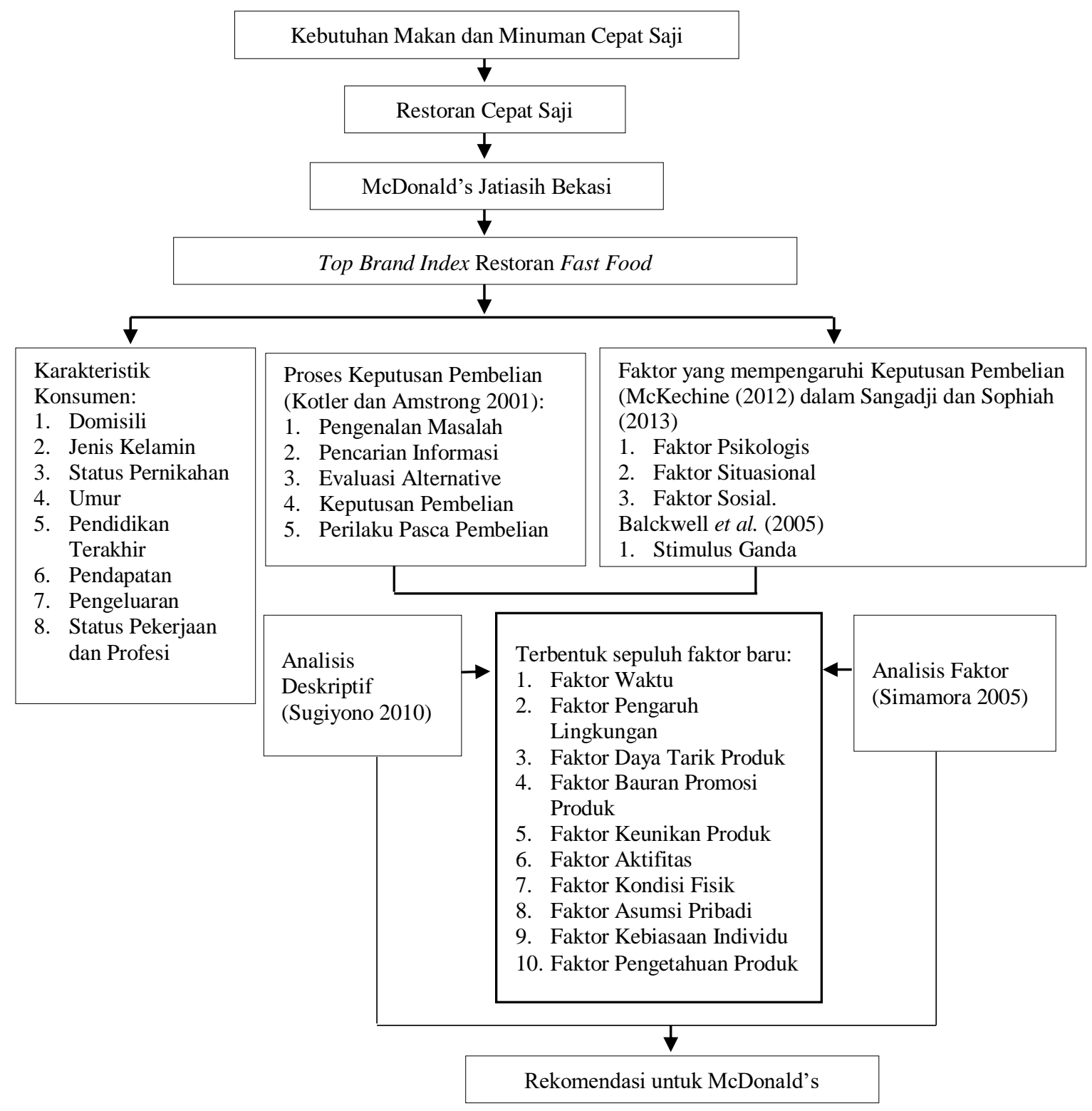

Gambar 3. Kerangka Pemikiran

Jurnal Manajemen dan Organisasi (JMO),

Vol. 9 No. 3 , Desember 2018 Hal. 191-201
Jenis data yang digunakan dalam penelitian ini adalah data primer dan data sekunder. Sampel dalam penelitian ini adalah konsumen McDonald's Jatiasih Bekasi. Metode pengambilan sampel adalah menggunakan metode non probability sampling dengan teknik Accidental Sampling yaitu bentuk pengambilan sampel berdasarkan siapa saja yang kebetulan bertemu 
dengan penulis dan dianggap cocok menjadi responden penelitian ini. Jumlah sampel dalam penelitian ini dihitung menggunakan rumus Slovin.

$$
\mathrm{n}=\frac{179200}{1+179200(0.1)^{2}}=99.94 \approx 100
$$

Sasaran penelitian ini merupakan konsumen McDonald's Jatiasih dan minimal sudah pernah datang ke restoran McDonald's Jatiasih Bekasi dan melakukan pembelian produk satu kali dalam dua bulan terakhir terhitung pada saat pengambilan data.

\section{HASIL DAN PEMBAHASAN}

\section{Gambaran Umum McDonald's}

Restoran McDonald's pertama di Indonesia terletak di Sarinah, Jakarta dan pertama kali dibuka pada tanggal 23 Februari 1991. Lisensi waralaba McDonald's Corporation USA di Indonesia dikelola oleh Rekso, perusahaan induk dari beberapa perusahaan terkemuka yang terdiri atas Sinar Sosro, Rekso Nasional Food, Gunung Slamat, dan Agro Pangan. PT Rekso Nasional Food adalah master franchisee (perkembangan lisensi) Corporation McDonald's USA di Indonesia yang mengoperasikan lebih dari 100 outlet McDonald's di seluruh negeri.

\section{Karakteristik Konsumen}

Berdasarkan karakteristik jenis kelamin, persentase konsumen McDonald's Jatiasih Bekasi berjenis kelamin perempuan sebesar 55\% sedangkan untuk laki-laki adalah $45 \%$. Perbedaan jumlah tersebut tidak terlalu signifikan karena menurut hasil pengamatan di lapangan pengunjung pria dan wanita biasanya datang bersama-sama. Karakteristik domisili konsumen McDonald's Jatiasih berasal dari berbagai wilayah khususnya Bekasi Selatan, Bogor dan Bekasi Timur. Konsumen McDonald's Jatiasih didominasi oleh masyarakat yang berdomisili di Bekasi Selatan sebesar 49\%, Bogor 24\% dan Bekasi Timur 9\%. Hal tersebut menunjukkan banyak masyarakat Bekasi Selatan khususnya Jatiasih yang sudah terbiasa dengan budaya konsumsi makanan cepat saji.

Umumnya konsumen berasal dari wilayah Bekasi Selatan melakukan pembelian produk di McDonald's Jatiasih karena cepat dan praktis. Oleh karena itu, pihak manajemen restoran sebaiknya menyesuaikan pelayanannya dengan budaya masyarakat Bekasi Selatan yang bersifat modern dan dinamis. Persentase konsumen McDonald's Jatiasih berstatus belum menikah sebesar $84 \%$, sedangkan konsumen yang sudah menikah sebesar $16 \%$. Hal tersebut tidak terlepas dari mayoritas konsumen McDonald's Jatiasih yang berusia dewasa awal yaitu 21-25 tahun dan berstatus sebagai pelajar/mahasiswa.

Mayoritas konsumen McDonald's Jatiasih Bekasi didominasi oleh konsumen dengan usia dewasa yaitu usia 21-25 tahun sebesar 50\% dan 15-20 tahun sebesar 31\%. Usia muda maupun beranjak dewasa merupakan usia aktif dan senang ke tempat-tempat tertentu untuk memenuhi aktifitas sehari-hari ataupun mengerjakan tugas bersama teman-teman. Konsumen McDonald's Jatiasih Bekasi didominasi oleh konsumen dengan pendidikan terakhir SMA sebesar 52\%, kemudian diikuti oleh S1 sebesar 28\% dan Diploma (I/II/III) sebesar 14\%. Hal ini menunjukkan mayoritas konsumen McDonald's Jatiasih Bekasi didominasi oleh konsumen yang berpendidikan cukup tinggi. Konsumen McDonald's Jatiasih Bekasi didominasi oleh konsumen yang belum bekerja atau masih berstatus sebagai pelajar/mahasiswa, yaitu dengan persentase sebesar $57 \%$. Berdasarkan hasil penelitian, tujuan konsumen yang berstatus pelajar/mahasiswa melakukan pembelian produk karena ingin berkumpul bersama teman-teman sambal mengerjakan tugas ataupun bercengkrama dengan teman-teman.

Mayoritas konsumen McDonald's Jatiasih Bekasi berprofesi sebagai siswa/i SMA sebesar $18 \%$, diikuti oleh dosen/guru sebesar $11 \%$. Hal ini tidak terlalu signifikan karena pada wilayah Jatiasih terdapat cukup banyak sekolah dari SMP hingga SMA/SMK sehingga banyak kalangan siswa/i memilih McDonald's sebagai tempat berbincang bersama teman dan mengerjakan tugastugas kelompok sekolah. Mayoritas konsumen McDonald's Jatiasih Bekasi mempunyai pendapatan rata-rata per bulan di bawah Rp 1.000.000,- sebesar 43\%. Hal tersebut sesuai dengan karakteristik status pekerjaan konsumen McDonald's Jatiasih Bekasi yang menunjukkan

Jurnal Manajemen dan Organisasi (JMO),

Vol. 9 No. 3 , Desember 2018, Hal. 191-201 
mayoritas pekerjaan sebagai pelajar/mahasiswa dengan pendidikan terakhir SMA yang mana pada usia tersebut biasanya pendapatannya masih di bawah Rp 1.000.000,-.

Mayoritas konsumen McDonald's Jatiasih mengeluarkan biaya Rp 50.000,- per bulan untuk pembelian produk McDonald's sebesar 26\%, diikuti dengan pengeluaran Rp 100.000,- per bulan untuk pembelian produk McDonald's sebesar 22\%. Perbedaan jumlah pengeluaran tersebut tidak terlalu signifikan karena berdasarkan hasil penelitian rata-rata penghasilan konsumen McDonald's Jatiasih di bawah Rp 1.000.000,- per bulan. Hal ini sangat sesuai dengan hasil survei karakteristik berdasarkan pendapatan konsumen, karakteristik berdasarkan status pekerjaan konsumen dan karakteristik berdasarkan pendidikan terakhir konsumen. Umumnya konsumen McDonald's Jatiasih Bekasi melakukan pembelian produk karena dipengaruhi faktor harga, karena pada McDonald's sendiri terdapat varian menu yang harganya sangat bersahabat bagi keuangan pelajar/mahasiswa.

\section{Proses Pengambilan Keputusan Pembelian Konsumen}

Multifiah (2002) menjelaskan bahwa perilaku konsumen akan menentukan proses pengambilan keputusan dalam pembelian mereka. Berdasarkan teori Kotler dan Amstrong (2001), proses yang diambil konsumen untuk melakukan pengambilan keputusan pembelian terbagi kedalam lima tahap, yaitu pengenalan masalah, pencarian informasi, evaluasi alternatif, keputusan pembelian, perilaku pasca pembelian.

\section{Pengenalan Masalah}

Pengenalan masalah merupakan tahap pertama dari proses pengambilan keputusan pembelian konsumen di mana konsumen mengenali suatu masalah atau kebutuhan dan hal-hal apa yang memberikan motivasi tertinggi. Motivasi konsumen McDonald's Jatiasih melakukan pembelian produk: cepat dan praktis, telah dipilih oleh 40 konsumen. Konsumen McDonald's Jatiasih menyukai pelayanan yang cepat dan praktis hal tersebut mampu mempengaruhi motivasi membeli produk, seiring dengan perkembangan zaman yang menuntut konsumen untuk beraktifitas secara dinamis dan aktif. Manfaat yang didapat konsumen setelah konsumsi McDonald's: menghilangkan rasa lapar, telah dipilih oleh 64 konsumen. Sebagian besar menjawab menghilangkan rasa lapar setelah konsumsi produk McDonald's karena porsi yang disediakan pas dengan kapasitas daya tampung makanan dan minuman setiap konsumen.

\section{Pencarian Informasi}

Sumber informasi utama konsumen sebelum melakukan keputusan pembelian adalah: sumber pribadi, telah dipilih oleh 54 konsumen. Sumber pribadi terdiri dari keluarga, teman, tetangga dan kenalan. Sumber pribadi merupakan hal yang paling mudah dan terpercaya dalam pencarian informasi, karena sumber-sumber yang dipilih merupakan orang-orang terdekat dan yang sering melakukan komunikasi secara intens. Pengaruh iklan/promosi dipilih oleh 54 konsumen sama dengan banyaknya konsumenn yang memilih sumber pribadi, iklan atau promosi yang tepat akan menciptakan nilai jual produk yang lebih di mata konsumen dan menarik minat konsumen untuk berkunjung. Fokus utama perhatian konsumen McDonald's Jatiasih Bekasi terkait promo McDonald's adalah produk baru dipilih oleh 48 konsumen. Produk baru menjadi perhatian utama dalam pencarian informasi melalui sumber pribadi yang dilakukan oleh konsumen, dengan hadirnya produk-produk baru yang dikeluarkan oleh McDonald's membuat konsumen tidak bosan untuk datang kembali ke McD Jatiasih Bekasi.

\section{Evaluasi Alternatif}

Informasi yang sudah didapat selanjutnya dievaluasi oleh konsumen, yaitu suatu tahap dalam proses pengambilan keputusan pembelian dimana konsumen menggunakan informasi untuk mengevaluasi merek-merek alternatif dalam satu susunan pilihan. Atribut utama yang menjadi pertimbangan konsumen dalam pembelian produk McDonald's Jatiasih Bekasi adalah

Jurnal Manajemen dan Organisasi (JMO),

Vol. 9 No. 3 , Desember 2018 Hal. 191-201 harga produk dipilih oleh 26 konsumen. Harga yang sesuai dengan karakteristik konsumen meningkatkan pangsa pasar suatu produk dan memberikan dampak yang postif terhadap perkembangan produk dalam jangka panjang. Salah satu indikator keberhasilan suatu usaha seperti restoran adalah sikap loyal konsumen terhadap restoran tersebut. Apabila konsumen menghadapi situasi yang tidak diharapkan seperti produk yang diinginkan tidak tersedia, alternatif 
yang dipilih konsumen McDonald's Jatiasih adalah membeli produk McDonald's lainnya dipilih oleh 75 konsumen, dan hanya 11 konsumen yang memilih untuk tidak jadi membeli produk McDonald's apabila produk yang diinginkan tidak tersedia. Hal ini menunjukkan brand image McDonald's Jatiasih sudah melekat di konsumennya sehingga menimbulkan loyalitas yang tinggi dari pihak konsumen.

4. Keputusan Pembelian Konsumen

Menurut Peter et al. (2000), pengambilan keputusan konsumen adalah proses pemecahan masalah yang diarahkan pada sasaran. Setelah melakukan pengenalan masalah, pencarian informasi dan evaluasi berbagai alternatif konsumen akan melakukan keputusan pembelian cara konsumen memutuskan pembelian produk McDonald's tidak terlalu signifikan. Konsumen yang melakukan pembelian produk secara tidak direncanakan kemudian membeli produk atau paket McDonald's dipilih oleh 35 konsumen dan konsumen yang melakukan pembelian produk sudah direncanakan sebelumnya kemudian membeli dipilih oleh 30 konsumen. Hasil penelitian tersebut menunjukkan tidak semua konsumen McDonald's Jatiasih loyal, karena konsumen yang loyal pastinya akan merencanakan kemudian membeli produk McDonald's.

Teman merupakan sosok paling mempengaruhi konsumen McDonald's Jatiasih Bekasi untuk melakukan pembelian produk (dipilih oleh 48 konsumen). Hal ini menunjukkan bahwa sosok teman dengan cara word of mouth atau dari mulut ke mulut akan sangat mempengaruhi konsumen dalam keputusan pembelian produk. Selain tidak membutuhkan biaya, biasanya sosok teman akan memberikan masukkan dengan cara yang sedikit memaksa. Namun di sisi lain saat melakukan pembelian produk McDonald's pastinya akan lebih menyenangkan bila dilakukan bersama teman-teman. diketahui frekuensi terbanyak konsumsi produk McDonald's yang dipilih konsumen selama satu bulan adalah 2 kali dipilih oleh 33 konsumen. Harga produk McDonald's terbilang cukup tinggi bila dibandingkan harga makanan lokal. Hal ini disebabkan karena karakteristik konsumen berdasarkan status pekerjaan McDonald's Jatiasih Bekasi merupakan pelajar/mahasiswa, biasanya mayoritas di usia ini belum memiliki pekerjaan sehingga tidak akan mampu terlalu sering konsumsi McDonald's.

Paket makanan McDonald's yang paling sering dibeli oleh konsumen adalah paket andalan sebanyak 74 orang. Paket andalan banyak disukai oleh konsumen karena terdapat paket nasi dan ayam goreng, sudah tidak asing bagi tradisi masyarakat Indonesia yang terbiasa makan nasi untuk memenuhi kebutuhan sehari-hari untuk beraktifitas. Kurang puas rasanya setelah makan tidak minum, oleh karena itu pihak McDonald's menyediakan beraneka ragam paket minum. Disimpulkan paket minuman yang menjadi favorit konsumen McDonald's Jatiasih adalah paket minuman dipilih oleh 47 konsumen.

5. Perilaku Pasca Pembelian

Setelah membeli produk, konsumen bisa puas atau tidak puas, dan akan terlibat dalam perilaku pasca pembelian. Perilaku pasca pembelian merupakan tahap dalam proses pengambilan keputusan pembelian di mana konsumen mengambil tindakan lebih lanjut setelah membeli berdasarkan kepuasan atau ketidakpuasan yang mereka rasakan. Konsumen mendasarkan harapan pada informasi yang diterima dari penjual, teman dan sumber lainnya.

Sebanyak 80 konsumen merasa puas terhadap produk yang disediakan oleh McDonald's. Sebanyak 20 konsumen merasa sangat puas dan tidak ada konsumen yang tidak puas atas pelayanan dan produk yang ditawarkan oleh McDonald's. Hal ini menunjukkan bahwa ekspektasi konsumen terhadap cita rasa produk, tampilan produk sudah sangat sesuai dan manajemen restoran sudah berhasil memberikan pelayanan terbaik kepada konsumen. Sebanyak 98 konsumen akan melakukan pembelian ulang di McDonald's Jatiasih hanya dua konsumen yang memilih tidak akan melakukan pembelian ulang. Hal tersebut menunjukkan tingkat kepercayaan dan kepuasan konsumen terhadap restoran McDonald's Jatiasih sangat tinggi baik dalam pelayanan, fasilitas yang tersedia, citarasa dan harga. Jika harga produk McDonald's yang diinginkan naik, sebanyak 69 konsumen akan tetap membeli produk McDonald's. Sedangkan 19 konsumen memilih restoran cepat saji lain dan 12 konsumen tidak membeli produk. Hal ini membuktikan sebagian besar konsumen sudah terikat dengan restoran cepat saji McDonald's dan tetap loyal apabila terjadi kenaikan harga pada produk yang diinginkan. 


\section{Faktor-faktor yang Mempengaruhi Keputusan Pembelian Konsumen}

Penelitian ini menggunakan empat item untuk analisis faktor, yaitu stimulus pemasaran, faktor psikologis, faktor situasional dan faktor sosial. Dari ke empat faktor tersebut terdapat 17 variabel, yaitu (1) produk , (2) harga , (3) promosi , (4) tempat, (5) persepsi , (6) motivasi, (7) pembelajaran, (8) sikap, (9) kepribadian, (10) sarana dan prasarana tempat berbelanja, (11) waktu berbelanja, (12) kondisi pembelian, (13) undang-undang, (14) keluarga, (15) kelompok referensi, (16) kelas sosial dan (17) budaya. Dari 17 variabel tersebut terbentuk 36 indikator.

Pengolahan data awal adalah memasukkan 17 variabel ke dalam analisis faktor yang menghasilkan angka Kaiser-Meyer-Olkin (K-M-O). K-M-O yang nilainya antara 0,5 - 1,0 menunjukkan bahwa analisis faktor layak diterapkan, jika nilai analisis K-M-O di bawah 0,5 analisis faktor tidak dapat diterapkan. Pengolahan data awal menghasilkan angka Kaiser-MeyerOlkin (K-M-O) dan Measure of Sampling Adequancy (MSA) sebesar 0.690, maka analisis faktor layak diterapkan dalam penelitian dan nilai Chi-Square pada Bartlett's Test sebesar 1765,556 dengan signifikansi 0,000 .

Setelah mengetahui hasil dari K-M-O, tahap selanjutnya adalah Anti Image Matrices, pada bagian ini terdapat Anti Image Covariance dan Anti Image Correlation. Hasil analisis faktor dilihat pada tabel Anti Image Correlation, pada tabel tersebut terdapat angka huruf 'as dan membentuk garis diagonal dari ujung kiri atas sampai ujung kanan bawah, angka pada garis diagonal tersebut menunjukkan hasil nilai MSA dengan persyaratan MSA harus di atas 0,5. Hasil pengolahan data membuktikan bahwa variabel-variabel yang ada dalam penelitian telah memenuhi persyaratan nilai MSA karena semua angka diatas 0,5 sehingga tidak ada variabel yang harus dikeluarkan. Seluruh variabel layak digunakan dan dapat dilakukan analisis faktor. Langkah selanjutnya adalah melihat tabel Communalities. Tabel Communalities adalah jumlah dari kuadrat masing-masing loading faktor. Semakin besar nilai Communalities maka semakin kuat hubungannya, sebaliknya apabila semakin kecil maka semakin lemah hubungannya.

Selanjutnya adalah mengetahui hasil dari tabel Total Variance Explained. Pada tabel ini terdapat Total Variance Explained Extracted Components dan Rotated Components. Hasil pengolahan data menunjukkan 10 faktor yang terbentuk dengan nilai eigenvalues lebih dari satu dengan keragaman data sebesar $73,736 \%$, artinya terbentuk sepuluh faktor yang mempengaruhi keputusan pembelian di McDonald's Jatiasih Bekasi dari keseluruhan faktor yang mempengaruhi.

Setelah melakukan semua tahap tersebut, tahap selanjutnya adalah rotasi menggunakan metode varimax dengan tahap rotasi matriks komponen akan mudah di interpretasi dibandingkan yang tidak di rotasi. Setiap variabel dari faktor yang terbentuk harus lebih besar dari 0,5 agar variabel tersebut dapat secara nyata menjadi bagian dari salah satu faktor yang terbentuk. Berdasarkan hasil Rotated Component Matrix terdapat tujuh variabel yang tidak memenuhi persyaratan, sehingga tersisa 29 variabel yang kemudian di kelompokkan ke dalam sepuluh faktor. Sepuluh faktor baru yang terbentuk setelah dilakukan analisis faktor.

1. Faktor Pengaruh Lingkungan

Faktor pertama dinamakan faktor pengaruh lingkungan. Faktor ini sangat mempengaruhi konsumen dalam pembelian produk McDonald's Jatiasih Bekasi dengan nilai eigenvalues terbesar yaitu 9,44. Faktor pengaruh lingkungan terdiri dari enam variabel yaitu orang tua, saudara, suami/istri, kesadaran kelas/mampu, berinteraksi, memilih McD dibandingkan restoran cepat saji lain. Hal ini menunjukkan bahwa pengaruh saudara merupakan variabel terpenting dalam faktor pertama, tentu saja pengaruh saudara merupakan faktor utama dalam keputusan pembelian produk McDonald's hal ini dikarenakan informasi dari saudara merupakan informasi yang akurat dan paling dipercaya, karena ke dua belah pihak sebelumnya sudah sering melakukan interaksi yang menimbulkan kepercayaan antar satu dengan yang lain.

Jurnal Manajemen dan Organisasi (JMO),

Vol. 9 No. 3 , Desember 2018 Hal. 191-201

\section{Faktor Kebiasaan Individu}

Faktor ke dua yang terbentuk yaitu kebiasaan individu, faktor ini memiliki nilai eigenvalues sebesar 4,44. Faktor kebiasaan individu terdiri dari empat variabel yaitu tanggapan pemenuhan kebutuhan, terikat/terbiasa, sekolah/kuliah dan malam hari. Faktor kebiasaan individu merupakan faktor terbesar ke dua yang terbentuk dengan keberagaman data yang mampu dijelaskan sebesar $12,337 \%$ dan nilai loading factor terbesar yaitu terikat atau terbiasa (VAR00035) sebesar 0,684. 
Hal tersebut menunjukkan keterikatan/kebiasaaan merupakan variabel terkuat dalam faktor kebiasaan individu, keterikatan/kebiasaan merupakan salah satu indikator terbentuknya budaya yang sering dipilih ketika menginginkan sesuatu.

3. Faktor Bauran Promosi Produk

Faktor ke tiga yang terbentuk yaitu bauran promosi produk, faktor ini memiliki nilai eigenvalues sebesar 2,39. Faktor ini memiliki nilai keberagaman data yang mampu dijelaskan sebesar 6,655 persen dan nilai loading factor terbesar yaitu keanekaragaman produk (VAR00004) sebesar 0,774 . Hal tersebut menunjukkan keanekaragaman produk merupakan variabel terkuat dalam faktor bauran promosi produk. Berdasarkan penelitian yang dilakukan oleh Jagajeevanrao L et al. (2018) dengan menyediakan berbagai pilihan produk akan meningkatkan keinginan konsumen untuk mencoba membeli produk lainnya dikunjungan selanjutnya. Keanekaragaman produk yang tersedia pada restoran akan menghilangkan rasa bosan konsumen untuk selalu datang dan membeli atau mencoba produk McD lainnya, karena dengan keanekaragaman produk konsumen akan selalu penasaran dengan citarasa yang dihasilkan atas keberagaman produk tersebut. Hal ini akan menimbulkan loyalitas konsumen yang tinggi dan meningkatkan citra restoran $\mathrm{McD}$ di mata konsumen.

\section{Faktor Aktifitas}

Faktor ke empat yang terbentuk yaitu aktifitas, faktor ini memiliki eigenvalues sebesar 2,20. Faktor aktifitas terdiri dari tiga variabel, yaitu reuni, meeting dan bola. Faktor ini memiliki nilai keberagaman data yang mampu dijelaskan sebesar 6,124\% dan nilai loading factor terbesar yaitu reuni (VAR00030) sebesar 0,735. Hal tersebut menunjukkan variabel reuni merupakan faktor terkuat dalam keputusan pembelian produk McD yang dilakukan oleh konsumen. Pada McDonald's Jatiasih Bekasi banyak konsumen yang datang dan membeli produk karena ingin melakukan reuni dengan teman-teman lama.

5. Faktor Waktu

Faktor ke lima yaitu waktu, faktor ini memiliki eigenvalues sebesar 1,68. Faktor waktu terdiri dari tiga variabel, yaitu sedih, siang hari dan sore hari. Faktor waktu merupakan factor ke lima terbesar yang terbentuk dengan nilai keberagaman data yang mampu dijelaskan sebesar $4,671 \%$ dan nilai loading factor terbesar yaitu siang hari (VAR00019) sebesar 0,839. Variabel siang hari sebagai faktor terkuat dalam keputusan pembelian produk McDonald's Jatiasih. Konsumen beranggapan kondisi daerah Jatiasih yang cukup panas di siang hari mempengaruhi keinginan konsumen untuk datang dan menyantap produk McDonald's terutama paket minuman dan pencuci mulut. Kedua produk ini sangat tepat untuk di santap pada siang hari.

6. Faktor Daya Tarik Produk

Faktor ke enam yaitu daya tarik produk, faktor ini memiliki eigenvalues sebesar 1,47. Terdiri dari tiga variabel, yaitu tampilan yang menarik, website dan juga harga. Faktor daya tarik produk sebagai faktor ke lima yang tebentuk memiliki keragaman data yang mampu dijelaskan sebesar 4,099\% dan nilai loading factor terbesar yaitu website (VAR00009) sebesar 0,790. Hal ini bisa dipahami karena konsumen perlu mengetahui informasi mengenai produk yang ingin dibeli baik dari sisi harga, website dan tampilan dari produk tersebut, karena pada zaman modern ini pencarian informasi menjadi lebih mudah dengan adanya internet. Selain mudah, pencarian dengan internet akan menimbulkan rasa kepuasan tersediri bagi konsumen apabila informasi yang didapat dengan produk yang dirasakan sesuai.

7. Faktor Asumsi Pribadi

Faktor ketujuh adalah asumsi pribadi, faktor ini memiliki eigenvalues sebesar 1,43. Terdiri dari tiga variabel, yaitu pengalaman baik, citarasa dan pengalaman menyenangkan. Faktor asumsi pribadi sebagai faktor terbesar ke tujuh yang tebentuk memiliki keragaman data yang mampu dijelaskan sebesar 3,982\% dan nilai loading factor terbesar yaitu pengalaman baik sebesar 0,695 (VAR00017). Pengalaman baik didapat berdasarkan pelayanan yang diberikan oleh McDonald's baik dalam keramahan pramusaji, rasa makanan, design interior dan eksterior, cita rasa makanan/minuman sesuai dengan ekspektasi konsumen. Memberikan pelayanan baik kepada konsumen akan memberikan kepuasan bagi konsumen dan akan meningkatkan citra restoran cepat saji. 


\section{Faktor Keunikan Produk}

Faktor kedelapan adalah keunikan produk, faktor ini memiliki eigenvalues sebesar 1,17 dan hanya memiliki satu variabel, yaitu tampilan produk nyaman dilihat. Faktor keunikan produk sebagai faktor terbesar ke delapan yang terbentuk memiliki keragaman data yang mampu dijelaskan sebesar 3,252\% dan nilai loading factor sebesar 0,767 (VAR00010). Seiring dengan perkembangan jaman, perkembangan restoran cepat saji berkembang secara cepat hal ini diiringi dengan kemunculan restoran-restoran cepat saji pesaing. Upaya untuk mensiasati hal tersebut dibutuhkan keunikan produk sebagai diferensiasi produk dengan para pesaing dan menciptakan nilai tersendiri yang mampu menarik perhatian konsumen McDonald's.

9. Faktor Pengetahuan Mengenai Produk

Faktor kesembilan adalah pengetahuan mengenai produk, faktor ini memiliki eigenvalues sebesar 1,17 dan hanya memiliki satu variabel, yaitu pengetahuan konsumen mengenai produk. Faktor pengetahuan mengenai produk sebagai faktor terbesar ke sembilan yang terbentuk memiliki keragaman data yang mampu dijelaskan sebesar 3,252\% dan nilai factor loading sebesar 0,550 (VAR00014). Keseharian masyarakat konsumen McDonald's Jatiasih tidak terlepas dari penggunaan internet, dengan kemudahan akses internet konsumen akan lebih mudah mendapatkan pengetahuan mengenai produk McDonald's yang ingin dibeli. Sumber pengetahuan produk yang didapatkan konsumen dapat juga melalui interaksi sesama teman, saudara atau pun orang tua yang sudah pernah melakukan pembelian produk McDonald's.

10. Faktor Kondisi Fisik

Faktor ini merupakan faktor terakhir yang terbentuk setelah melakukan analisis faktor, terdiri dari satu variabel sehat dengan nilai eigenvalues sebesar 1,02 dengan keragaman data yang mampu dijelaskan sebesar 2,835\% dan nilai factor loading sebesar 0,709 (VAR00022). McDonald's merupakan restoran makanan cepat saji dan kurang baik apabila dikonsumi berlebihan baik dalam keadaan sehat ataupun kurang sehat, oleh karena itu konsumen McDonald's Jatiasih melakukan pembelian produk makanan/minuman pada saat kondisi sehat.

\section{Implikasi Manajerial}

Berdasarkan hasil penelitian terhadap karakteristik konsumen, proses pengambilan keputusan pembelian dan faktor-faktor yang mempengaruhi konsumen dalam melakukan pembelian produk makanan dan minuman di McDonald's Jatiasih Bekasi, diperoleh hasil bahwa terdapat beberapa hal yang memberikan pengaruh dan harus diperhatikan oleh pihak restoran. Menurut Sopiah dan Sangadji (2013), untuk mengembangkan strategi pemasaran yang efektif, pemasar harus mengetahui jenis proses pemecahan masalah yang digunakan konsumennya untuk membuat keputusan pembelian. Pemasar yang menargetkan beberapa segmen pasar sekaligus, masing-masing dengan proses pemecahan masalah yang berbeda harus mengembangkan multistrategi untuk mempengaruhi hasil-hasil keputusan yang berbeda. Multistrategi tersebut adalah perilaku pilihan yang rutin, pengambilan keputusan yang terbatas dan pengambilan keputusan yang intensif.

1. Perilaku Pilihan yang Rutin

Pemasar merek yang telah mapan dan memiliki pangsa pasar yang besar harus terus memelihara merek mereka agar tetap ada pada prioritas utama konsumen. McDonald's sendiri termasuk restoran cepat saji yang telah mapan dan memiliki pangsa pasar yang besar. Berdasarkan hasil pengolahan data konsumen dengan analisis faktor, mayoritas konsumen McDonald's Jatiasih akan melakukan pembelian produk pada waktu siang hari. Oleh karena itu, pihak manajemen sebaiknya menambahkan variasi menu minuman dingin dan memberikan promopromo tertentu pada paket minuman hanya pada saat siang hari. Apabila hal tersebut dilakukan akan meningkatkan loyalitas konsumen McDonald's Jatiasih. Morais (2005) menyatakan bahwa

Jurnal Manajemen dan Organisasi (JMO),

Vol. 9 No. 3 , Desember 2018, Hal. 191-201 loyalitas pelanggan adalah komitmen pelanggan terhadap suatu merek toko atau pemasok, berdasarkan sikap yang sangat positif dan tercermin dalam pembelian ulang yang konsisten

2. Pengambilan Keputusan yang Terbatas

Sebagian besar keputusan konsumen membutuhkan upaya pemecahan masalah yang terbatas karena sebagian besar konsumen telah memiliki sejumlah besar informasi produk yang 
berasal dari pengalaman masa lalu. Dasar strategi pemasarannya adalah menyiapkan informasi tambahan agar tersedia bagi konsumen kapan pun dan di mana pun mereka membutuhkannya. Berdasarkan hasil pengolahan data konsumen dengan analisis faktor, konsumen McD Jatiasih melakukan pembelian produk dikarenakan terpengaruh oleh saudara dan website. Oleh karena itu sebaiknya pihak McDonald's mempertahankan kualitas pelayanan jasanya dengan memberikan pelatihan kepada para pramusaji dalam menghadapi konsumennya dan juga pihak McDonald's sebaiknya membuat tampilan yang lebih unik pada website McDonald's atau membuat website berdasarkan lokasi outlet McDonald's yang disesuaikan dengan karakteristik konsumen outlet tersebut. Hal tersebut diekspektasikan mampu meningkatkan citra McDonald's di mata konsumen dan mampu meningkatkan pangsa pasar.

3. Pengambilan Keputusan yang Ekstensif

Situasi pengambilan keputusan yang ekstensif di mana pengetahuan sangat rendah, konsumen membutuhkan informasi tentang segala sesuatu, termasuk tujuan akhir mana yang penting, alternatif pilihan mana yang relevan, kriteria pilihan mana yang tepat. Untuk hal ini manajemen McDonald's bisa melakukan cara baru dalam mempromosikan produk barunya, seperti melakukan kupon gratis dengan kriteria terntu (bawa pulang dan tukarkan kupon setelah beberapa kali melakukan pembelian produk baru) hal ini bertunjuan untuk mebantu konsumen mendapatkan pengetahuan tentang merek yang ditawarkan.

\section{KESIMPULAN}

Berdasarkan hasil penelitian dapat diketahui karakteristik konsumen McDonald's Jatiasih, mayoritas konsumen berdomisili di Bekasi Selatan, berstatus belum menikah, berusia muda, tingkat pendidikan terakhir SMA, berjenis kelamin perempuan, status pekerjaan atau kegiatan adalah pelajar/mahasiswa, profesi pekerjaan adalah siswa/i SMA, pendapatan per bulan di bawah satu juta rupiah, pengeluaran per bulan untuk pembelian produk McDonald's adalah sebesar lima puluh ribu rupiah. Proses pengambilan keputusan pembelian konsumen terbagi menjadi lima tahap, tahap pertama pengenalan masalah, motivasi konsumen melakukan pembelian produk adalah cepat dan praktis, manfaat yang didapat konsumen setelah konsumsi McDonald's adalah menghilangkan rasa lapar. Tahap kedua yaitu sumber informasi konsumen, sebelum konsumen melakukan pembelian produk konsumen memperoleh sumber informasi terkait produk McDonald's melalui sumber pribadi, pengaruh iklan/promosi yang dilakukan pihak terkait menarik perhatian konsumen sehingga konsumen melakukan pembelian produk, informasi yang menjadi fokus konsumen ketika mendengar promo tentang McDonald's adalah info terkait produk baru. Tahap ketiga adalah evaluasi alternaif. Atribut yang menjadi pertimbangan konsumen sebelum membeli produk di McDonald's adalah harga produk, alternatif yang dipilih konsumen ketika terjadi situasi tidak diharapkan (produk/paket yang diinginkan tidak tersedia) adalah membeli produk atau paket McDonald's lainnya.

Tahap keempat keputusan pembelian menyatakan bahwa cara konsumen memutuskan melakukan pembelian di McDonald's adalah tidak direncanakan kemudian membeli, sosok yang paling mempengaruhi keputusan pembelian produk McDonald's adalah teman, rata-rata konsumsi konsumen McDonald's Jatiasih dalam satu bulan adalah dua kali. Paket makanan favorit konsumen adalah paket andalan, apabila diurutkan berdasarkan produk makanan favorit konsumen, yaitu a) PaNas 1, b) PaNas 2, c) PaNas Special, d) Cheeseburger, e) Happy Meal Chicken. Paket minuman favorit konsumen McDonald's Jatiasih Bekasi adalah paket minuman, apabila diurutkan berdasarkan produk minuman terfavorit, yaitu a) McFlurry Oreo, b) Ice Lemon Tea, c) Iced Milo, d) Iced Cappucino. Tahap kelima perilaku pasca pembelian mengindikasikan bahwa konsumen merasa puas akan produk makanan dan minuman yang ditawarkan oleh McDonald's, konsumen akan melakukan pembelian ulang di McDonald's Jatiasih Bekasi, dan konsumen akan tetap membeli produk McDonald's apabila terjadi kenaikan harga produk. Faktorfaktor yang mempengaruhi konsumen dalam melakukan pembelian produk di McDonald's ada sepuluh, yaitu faktor pengaruh lingkungan, kebiasaan individu, bauran promosi produk, aktifitas, waktu, daya tarik produk, asumsi pribadi, keunikan produk, pengetahuan mengenai produk dan

Jurnal Manajemen dan Organisasi (JMO),

Vol. 9 No. 3 , Desember 2018 , Hal. 191-201 
kondisi fisik. Dari sepuluh faktor tersebut, variabel yang paling dominan adalah faktor waktu dengan variabel siang hari sebagai pilihan utama konsumen dalam konsumsi produk McDonald's.

\section{DAFTAR PUSTAKA}

[BPS] Badan Pusat Statistik. 2017. Konsumsi Kalori dan Protein Penduduk Indonesia dan Provinsi 2013 - 2017 [internet]. Bogor (ID): Badan Pusat Statistik [diunduh 2018 Mei 14]. Tersedia pada: http://www.bps.go.id.

Jagajeevanrao L, Susmitha V, Pavansahitya R, Lakshmi GS. 2018. Factors Influencing Customer Purchase Decision. International Journal of Engineering \& Technology [internet]. [diunduh 2018 Agu 15]; 7(2.7):958-962.doi: 10.14419/ijet.v7i.7.11435.

Multifiah, Titik. 2002. Perilaku Konsumen, Sebuah Pengantar. Malang (ID): PPS Universitas Brawijaya.

Kotler P, Amstrong G. 2001. Prinsip-Prinsip Pemasaran. Jilid 1. Ed ke-8. Jakarta (ID): Erlangga.

Peter, Paul J, Olson JC. 2000. Consumer Behaviour: Perilaku Konsumen dan Strategi Pemasaran. Jilid 2. Ed ke-4. Jakarta (ID): Erlangga.

Sangadji EM, Sopiah. 2013. Perilaku Konsumen. Yogyakarta (ID): ANDI.

Basu Swastha, Irawan. 2003. Manajemen Pemasaran Modern. Yogyakarta (ID): Liberty Offset.

Top Brand Award. 2017. Top Brand Index 2017 Fase 2 Kategori Retail. [Internet]. [diakses 15 Mei 2018] Tersedia pada http://www.topbrand-award.com/top-brand-survey/surveyresult/top_brand_index_2017_fase_2

Morais DB. 2013. Perilaku Konsumen. Sangadji M, Sopiah, penerjemahl Nikoemus WK, editor. Yogyakarta (ID): Penerbit ANDI. Terjemahan dari: Fostering Loyal Customer Relationship. 